\title{
Maternal and Paternal Characters Affecting the Growth and Survival of Progeny of Jayanti Rohu (Female) $\times$ Rohu (Male) and Jayanti Rohu (Male) $\times$ Rohu (Female)
}

\author{
Vivek Singh Bisht ${ }^{1}$, Anurag Semwal ${ }^{1}$, Sagar Vijay Kuveskar ${ }^{2}$, \\ Vibha Lohani $^{2^{*}}$ and R.N. Ram ${ }^{2}$ \\ ${ }^{1}$ Department of Aquatic Environment Management, ${ }^{2}$ Department of Fisheries Resource \\ Management, College of Fisheries, G. B. P. U. A \& T, Pantnagar, Uttarakhand, India \\ *Corresponding author
}

\begin{tabular}{|c|c|}
\hline & A B S T R A C T \\
\hline Keywords & \multirow{3}{*}{$\begin{array}{l}\text { The present study emphasizes how the maternal and paternal characters affect the } \\
\text { embryonic development, growth and survival of the young ones in the controlled } \\
\text { conditions. Healthy males and females of Jayanti Rohu (improved variety of Labeo rohita) } \\
\text { and Rohu (Labeo rohita) were induced to breed in the captive condition with suitable } \\
\text { physico-chemical parameters like water movement, water exchange, water temperature } \\
\text { and dissolved oxygen. The embryos were observed under the microscope. Eggs and young } \\
\text { ones were kept under observation for } 31 \text { days, placed in the setup with continuous water } \\
\text { flow, aeration and proper feeding. The present study revealed that the young ones of cross } \\
\text { of Jayanti Rohu (Female) } \times \text { Rohu (Male) had a better growth, survival, and faster } \\
\text { embryonic development as compared to the young ones of cross of Jayanti Rohu (Male) } \times \\
\text { Rohu (Female). }\end{array}$} \\
\hline Article Info & \\
\hline $\begin{array}{l}\text { Accepted: } \\
\text { 10 November } 2018 \\
\text { Available Online: } \\
10 \text { December } 2018\end{array}$ & \\
\hline
\end{tabular}

\section{Introduction}

Rohu (Labeo rohita) Hamilton (1822) is a species from family Cyprinidae. It is omnivore species found in the river of South Asia. This is an Indo-Gangetic riverine species and natural inhabitant of the riverine system of northern and central India. Rohu also inhabits the river of Bangladesh, Myanmar, Pakistan. It has different life stages with specific food preference, majorly feeding on zooplankton and some smaller phytoplankters like desmids, algal spores and phytoflagellates (Khan and
Siddiqui, 1973; Majumder et al., 2016). It has a nibbling type of mouth and soft fringed lips with sharp cutting edges. Teeth are not found in the bucco-pharyngeal region which makes the fish able to feed on soft aquatic vegetation which does not require seizure and crushing. They have well developed and modified thin gill rakers which help them to sieve water to eat phytoplankton. Jayanti Rohu is the first genetically improved variety of Rohu in India developed through selective breeding of Rohu collected from different waters of North India. Selective breeding of rohu has been initiated 
for the first time to genetically improve Rohu for better growth in India by ICAR-CIFA (Central Institute of Freshwater Aquaculture) in collaboration with Institute of Aquaculture Research (AKVAFORSK), Norway. Rohu (Labeo rohita) has been chosen as the candidate species for selective breeding because its consumer preference is very high. Jayanti Rohu has $17 \%$ higher growth efficiency per generation has been reported (Handbook of Fisheries and Aquaculture, Ayyappan et al., 2006).

Larval growth is strongly linked to individual life history traits such as size and growth, but the processes that influence variability in these traits are poorly understood. We investigate the relative significance of maternal and paternal influences on the larval growth. Parental effects on the growth rate of fish are readily acknowledged and incorporated by breeding and selection (Kinghorn, 1983; Dunham et al., 1987). Environmental factors encompass the physical and biotic processes acting on developing eggs and larvae. However, in wild fish populations, less than $40 \%$ of the variation in larval growth is accounted by environmental factors (Wilson and Meekan, 2002; Caldarone et al. 2003). It suggests that other processes, like parental effects, must account for a substantial amount of variability in growth. In general, due to the nutritional provisioning of an embryo, the maternal contributions are considered more important than paternal contributions (Bernado, 1996). In fishes, embryo and larval characteristics such as egg size, developmental rate, metabolism, growth and viability are affected by the body condition and genotype of the Female parent (Chambers et al., 1989; Chambers and Leggett, 1996; Kerrigan, 1997; Marteinsdottir and Steinarsson, 1998). Nongenetic maternal contributions take many forms that directly influence survival probabilities of larvae, including nutritional reserves (Kerrigan, 1997), levels of developmental, metabolic hormones (Brown et al., 1988, McCormick, 1998), and parental care (Bernado, 1996). While paternal effects have been identified in fishes (Heath et al., 1993; Herbinger et al., 1995; Hoie et al., 1999a; Yamamoto and Reinhardt, 2003), they are not detectable in all larval traits (Hoie et al., 1999b) and are often not considered. Research on maternal effects in marine fishes has engrossed on commercially important species, which generally spawn benthic eggs or pelagic eggs and show no parental care (e.g. Altantic cod Gadus morhua, capelin Mallotus villosus; Chambers and Leggett, 1996). Males are generally responsible for nest-tending and nest-site selection in species that lay benthic eggs, (Clutton-Brock, 1991). Development of offspring is enhanced by parental care (Sargent, 1997). Therefore, it is a mechanism by which males can devote in the survival potential of their offspring. Consequently, it is likely that variation in the size and condition of offspring from parentally tended eggs will reflect the male's contribution (Bernado, 1996). The present study is to examine the effect of maternal and paternal characters on the embryonic development, growth and survival of the young ones of Jayanti Rohu $($ Female) $\times$ Rohu (Male) and Jayanti Rohu (Male) $\times$ Rohu (Female) .

\section{Materials and Methods}

\section{Experimental fish}

For the experiment, we selected healthy matured brooders of Jayanti Rohu and Rohu of +2 Age group from the Experimental fish farm of College of Fisheries, G.B.P.U.A\&T, Pantnagar, Uttarakhand the length and weight of the selected brooders are given in table 1 and 2.

\section{Hormone injection and the dose of hormone}

The brooders were injected (intramuscular) with the hormone GonoPro-FH which is a gonadotropin-releasing hormone. It is a new 
highly potent and ready to use an injectable formulation containing a synthetic peptide analogous to the naturally occurring hormone salmon GnRH. The formulation also contains a dopamine antagonist. One-time dose of 0.20$0.40 \mathrm{mg} / \mathrm{kg}$ for female and $0.10-0.20 \mathrm{mg} / \mathrm{kg}$ for male was injected.

\section{Experimental condition}

After the injection, brooders of Jayanti Rohu (Female) and Rohu (Male) were kept in breeding tank one and Jayanti Rohu (Male) and Rohu (Female) were kept in breeding tank two. The continuous movement of water was maintained in both the tanks for the successful spawning, fertilization and survival. Continuous aeration with the help of showers was maintained in both the breeding tanks. After the spawning eggs of Jayanti Rohu (Female) $\times$ Rohu (Male) and Jayanti Rohu (Male) $\times$ Rohu (Female) were transferred to the hatching tank 1 and 2 respectively.

\section{Collection of fertilized eggs}

Spawning and fertilization took place in the hatchery in captive condition. Fertilized eggs were collected with the help of scoop net. Defective eggs were discarded and only the healthy eggs were taken to observe the different stages of development of embryos with the help of over-mounted digital microscope camera connected to a computer (Motic Digital Microscope).

\section{Sampling and data collection}

Sampling was done at regular intervals of time with the help of wide mouthed dropper and spatula. Eggs were collected and observed under the over-mounted digital microscope camera connected to a computer to determine the developmental stages and pictures were taken simultaneously. The sampling was more frequent in the initial stages of development of embryos because of rapid changes in the early embryonic stages. Eggs were examined daily, and the time periods of observations were $3 \mathrm{~h}$, 6h, 9h, 12h, 15h, 27h, 60h, 77h, 85h, 100h, and $110 \mathrm{~h}$. After $110 \mathrm{~h}, 100$ spawns were randomly collected from hatching tank one and two of Jayanti Rohu (Female) $\times$ Rohu (Male) and Jayanti Rohu (Male) $\times$ Rohu (Female) respectively and placed them in the setup made with two troughs with a continuous exchange of water. The cross of Jayanti Rohu (Female) $\times$ Rohu (Male) spawns were kept in trough one and the cross of Jayanti Rohu (Male) $\times$ Rohu (Female) spawns were kept in trough two. The nutritional feed was provided in both the troughs with the same amount. In the initial stages plankton was provided in both troughs. After few days powdered feed was mixed with the plankton was given in both the troughs and the data were observed.

\section{Results and Discussion}

The different embryonic developmental stages of Jayanti Rohu (Female) $\times$ Rohu (Male) and Jayanti Rohu (Male) $\times$ Rohu (Female) are compared in plate 1 .

After $3 \mathrm{~h}$ of fertilization, we observed that the eggs of Jayanti Rohu (Female) $\times$ Rohu (Male) were at the late morula stage whereas that of Jayanti Rohu (Male) $\times$ Rohu (Female) were still at early morula stage which shows the initial growth was slow in case of eggs of Jayanti Rohu (Male) $\times$ Rohu (Female). After 6 $\mathrm{h}$ of fertilization, we observed the blastodisc in Jayanti Rohu (Male) $\times$ Rohu (Female) whereas embryo hanging over yolk sac in Jayanti Rohu (Female) $\times$ Rohu (Male). Muscle segmentation started, and well differentiated head and the tail region was seen in Jayanti Rohu (Female) $\times$ Rohu (Male) after $9 \mathrm{~h}$ but no such muscle segmentation was observed in the developing embryos of Jayanti Rohu (Male) $\times$ Rohu (Female). A bigger size of yolk mass 
was seen in the embryos of Jayanti Rohu (Female) $\times$ Rohu (Male). Yolk mass plays an important role in the development and survival of embryo as it is the nutritional reserve of developing embryo (Kerrigan 1997). After 15 h, twitching movement was observed, which was faster in embryos of Jayanti Rohu (Female) $\times$ Rohu (Male). Eggs completely hatched between $15 \mathrm{~h}$ to $27 \mathrm{~h}$. Advanced brain vesicles and organ vesicles were seen in the hatchlings of Jayanti Rohu (Female) $\times$ Rohu (Male) after 27h. Development of eyes was observed after $60 \mathrm{~h}$ in both cases. After $77 \mathrm{~h}$ a fibrous ball of waste material was seen in both. After $100 \mathrm{~h}$ pectoral fins were visible in the hatchlings of
Jayanti Rohu (Female) $\times$ Rohu (Male) whereas no such development in the hatchlings of Jayanti Rohu (Male) $\times$ Rohu (Female) which developed the pectoral fins later. Complete yolk sac absorption was observed after $110 \mathrm{~h}$ of fertilization in both. After 110h, 100 spawns were observed for mortality rate at regular intervals of time for one month which is represented in table 3. On day $31^{\text {st }}$, 10 spawns were collected randomly from both the troughs and their length and weight was observed and depicted in table 4 and 5. We observed that maternal character not only affect the growth and survival of embryo but also the growth and survival of spawn.

Table.1 Length and weight of Jayanti Rohu (Male) $\times$ Rohu (Female)

\begin{tabular}{|c|c|c|c|c|}
\hline S.No & & \multicolumn{2}{|c|}{ Jayanti Rohu (Male) $\times$ Rohu (Female) } & \\
\hline & Weight(Kg) & Length(cm) & Weight(Kg) & Length(cm) \\
\hline 1 & 0.750 & 39.0 & 0.950 & 41.5 \\
\hline 3 & 0.750 & 41.2 & 1.000 & 42.0 \\
\hline 4 & 0.700 & 38.0 & 1.100 & 43.5 \\
\hline
\end{tabular}

Table.2 Length and weight of Jayanti Rohu (Male) $\times$ Rohu (Female)

\begin{tabular}{|l|c|c|c|c|}
\hline S.No & & \multicolumn{2}{|c|}{ Jayanti Rohu (Female) $\times$ Rohu (Male) } & \\
\hline & & & & \\
\hline & Weight(Kg) & Length(cm) & Weight(Kg) & Length(cm) \\
\hline 1 & 0.900 & 41.5 & 1.000 & 41.0 \\
\hline 2 & 1.250 & 46.5 & 0.500 & 29.5 \\
\hline 3 & 1.000 & 40.0 & 1.000 & 42.5 \\
\hline 4 & 0.750 & 38.0 & 0.900 & 41.5 \\
\hline
\end{tabular}


Table.3 Mortality of the hatchlings in troughs

\begin{tabular}{|c|c|c|}
\hline \multirow{2}{*}{$\begin{array}{c}\text { Days (After } \\
\text { fertilization) }\end{array}$} & \multicolumn{2}{|c|}{ Mortality (in numbers) } \\
\cline { 2 - 3 } & Jayanti Rohu(Female) $\times$ Rohu(Male) & $\begin{array}{c}\text { Jayanti } \\
\text { Rohu(Male) } \times \text { Rohu(Female) }\end{array}$ \\
\hline Day7 & 2 & 4 \\
\hline Day10 & 4 & 6 \\
\hline Day13 & 3 & 5 \\
\hline Day16 & 4 & 4 \\
\hline Day19 & 1 & 3 \\
\hline Day22 & 1 & 0 \\
\hline Day25 & 1 & 2 \\
\hline Day28 & 0 & 0 \\
\hline Day31 & 0 & 0 \\
\hline Total & 16 & 24 \\
\hline Survival & $\mathbf{8 4 \%}$ & $\mathbf{7 6 \%}$ \\
\hline
\end{tabular}

Table.4 Length (cm) of spawns of Jayanti Rohu(Female) $\times$ Rohu(Male) and Jayanti Rohu(Male $) \times$ Rohu(Female $)$ on day 31

\begin{tabular}{|c|c|c|}
\hline S.No. & Jayanti Rohu(Female) $\times$ Rohu(Male) & Jayanti Rohu(Male) $\times$ Rohu(Female) \\
\hline $\mathbf{1}$ & 1.0 & 1.4 \\
\hline $\mathbf{2}$ & 0.9 & 1.0 \\
\hline $\mathbf{3}$ & 1.0 & 1.0 \\
\hline $\mathbf{5}$ & 1.1 & 1.0 \\
\hline $\mathbf{6}$ & 1.0 & 0.9 \\
\hline $\mathbf{7}$ & 1.2 & 0.8 \\
\hline $\mathbf{8}$ & 1.1 & 0.9 \\
\hline $\mathbf{9}$ & 1.1 & 0.9 \\
\hline $\mathbf{1 0}$ & 1.0 & 1.0 \\
\hline Total & 1.1 & 1.0 \\
\hline Average & 10.5 & 9.9 \\
\hline length & 1.05 & 0.99 \\
\hline
\end{tabular}


Table.5 Weight of spawns of Jayanti Rohu(Female) $\times$ Rohu(Male) and Jayanti Rohu(Male) $\times$ Rohu(Female) on day 31

\begin{tabular}{|c|c|c|}
\hline Weight $(\mathrm{g})$ & Jayanti Rohu(Female) $\times$ Rohu(Male) & Jayanti Rohu(Male) $\times$ Rohu(Female) \\
\hline Total & 0.0840 & 0.0801 \\
\hline Average & $\mathbf{0 . 0 0 8 4}$ & $\mathbf{0 . 0 0 8 0}$ \\
\hline
\end{tabular}

Plate.1 Embryonic development of cross of Jayanti Rohu (Female) $\times$ Rohu (Male) and cross of Jayanti Rohu $($ Male $) \times$ Rohu $($ Female $)$

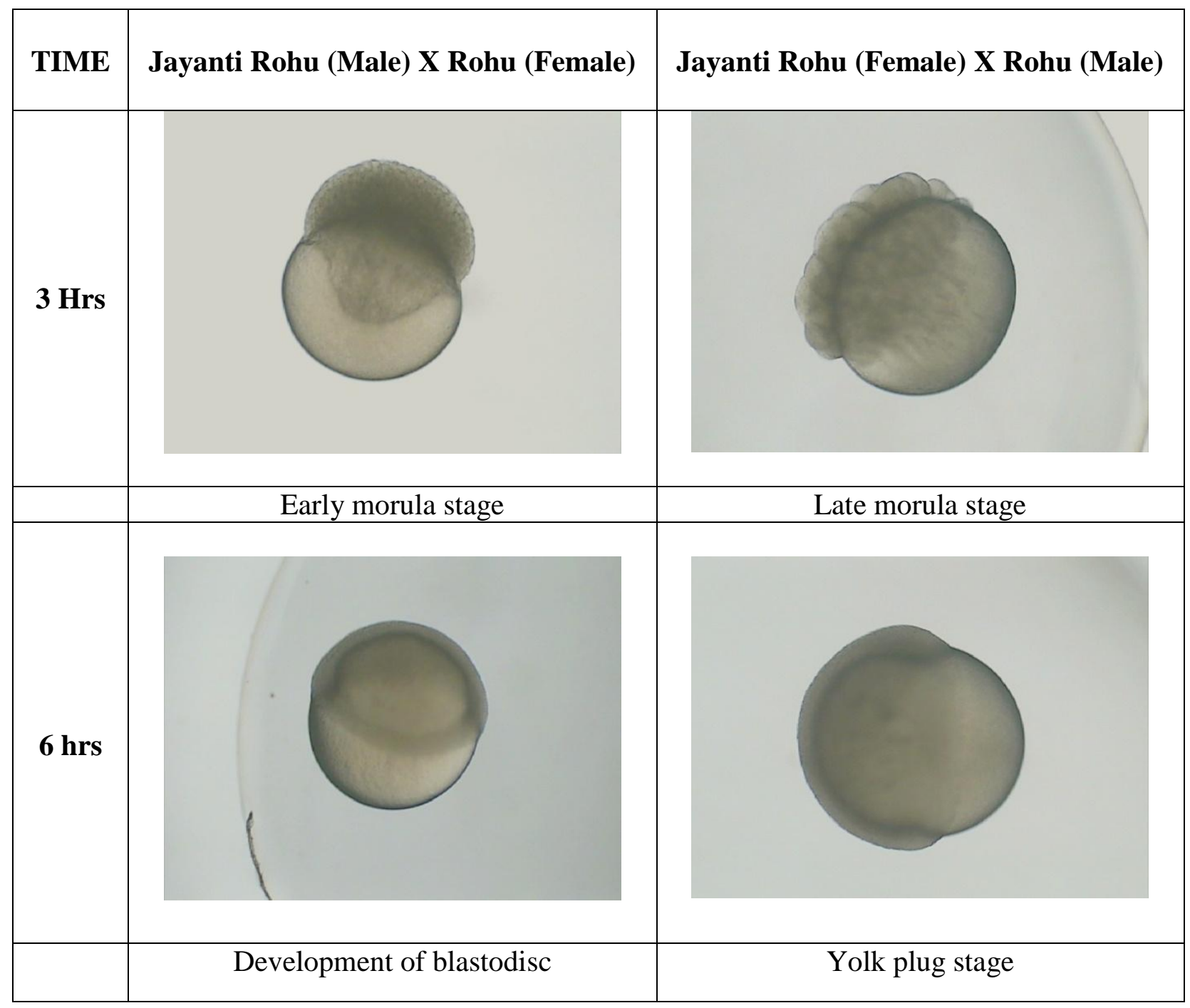




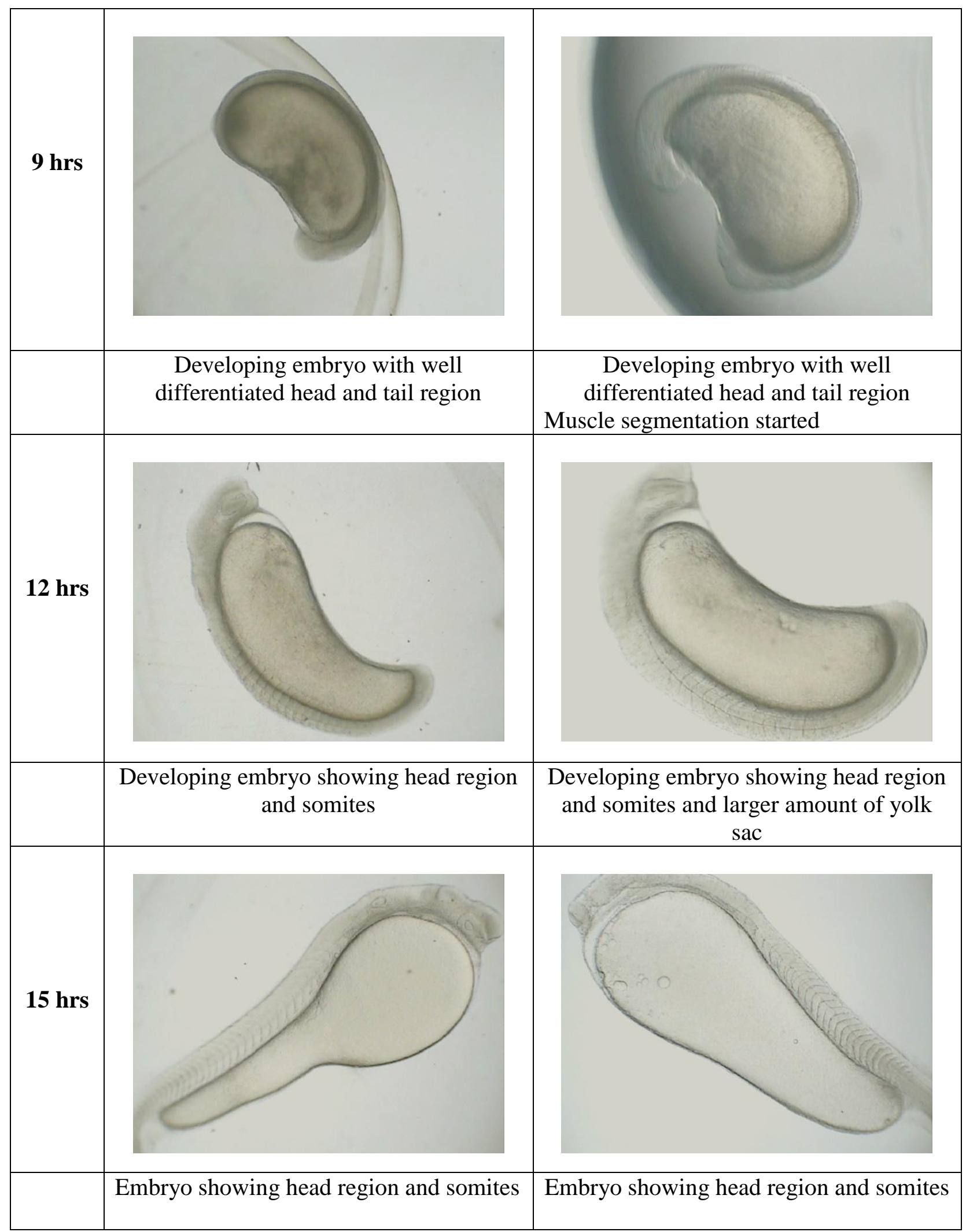




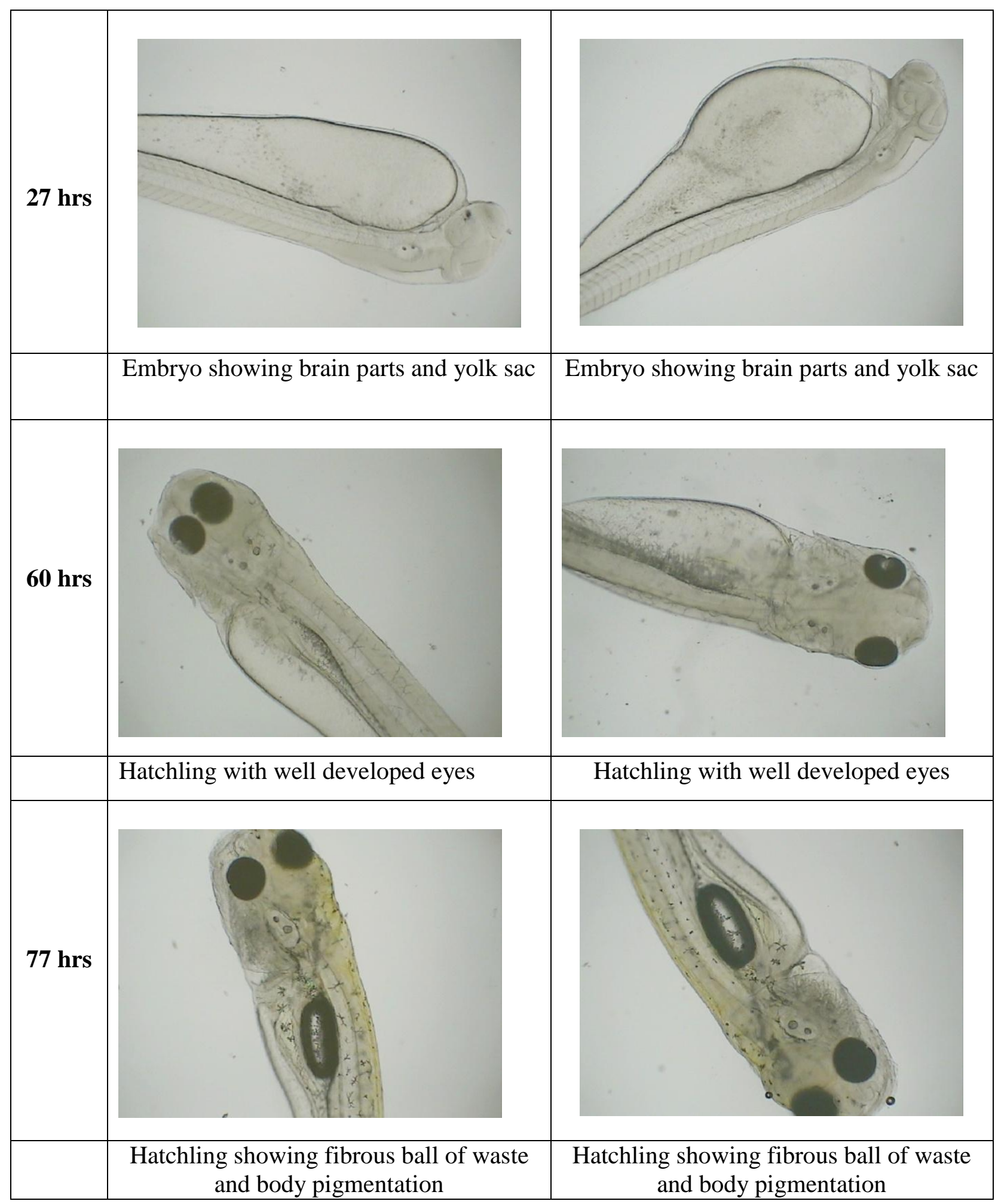




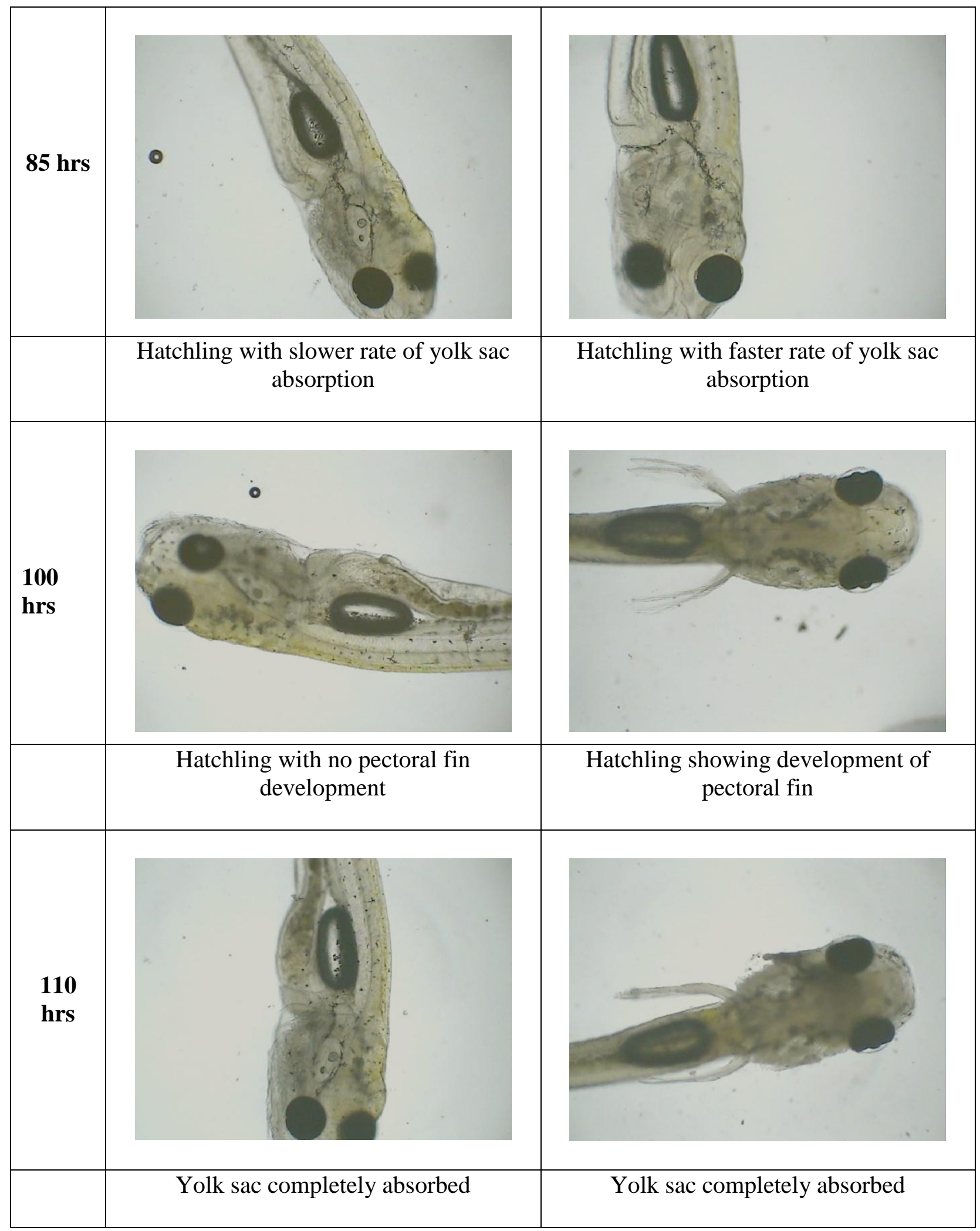


Mortality rate was counted every third day from the day of transfer of hatchlings in the troughs. On the $31^{\text {st }}$ day a total mortality of $16 \%$ in spawns of Jayanti Rohu (Female) $\times$ Rohu (Male) and 24\% in spawns of Jayanti Rohu (Male) $\times$ Rohu (Female) was observed. On the same day 10 spawns were randomly selected and length and weight of the spawns were taken with a scientific weighing scale. Spawns of Jayanti Rohu (Female) $\times$ Rohu (Male) showed an average length of $1.05 \mathrm{~cm}$ and weight of $0.0084 \mathrm{gm}$ on the other hand length and weight of spawns of Jayanti Rohu (Male) $\times$ Rohu (Female) were $0.99 \mathrm{~cm}$ and $0.0080 \mathrm{gm}$ respectively. Above calculations clearly indicates that embryo and spawn of Jayanti Rohu (Female) $\times$ Rohu (Male) had a better growth and survival compared to Jayanti Rohu (Male) × Rohu (Female). Embryonic development and survival depends on various factors like physico-chemical parameters of water, body size of brooders, age group of brooders, method of breeding, etc. Other than these, maternal and paternal traits play an important role in the development of embryo and survival. Similar results to the present study were reported by other studies which reveal that maternal characters play major role in development and survival of embryo and spawn (Bernado, 1996). In fishes, body condition and genotype of the female parent affects the embryo and larval characteristics such as egg size, developmental rate, metabolism, growth and viability (Chambers et al., 1989; Chambers and Leggett, 1996; Kerrigan, 1997; Marteinsdottir and Steinarsson, 1998). However, maternal traits are considered more important than the paternal traits due to nutritional provisioning of embryo (Bernado, 1996). In the present study we observed a better development and survival of embryo of Jayanti Rohu (Female) $\times$ Rohu (Male) than Jayanti Rohu (Male) $\times$ Rohu (Female). We observed that cross with female Jayanti Rohu showed a better development and survival which supports the fact that maternal character play major role in development and survival.

With the experiment conducted we may conclude that maternal characters play a more important role in the development and survival of the embryo and spawn as compared to the paternal characters. Because of the better maternal traits due to selective breeding of Jayanti Rohu (Female), the embryos of cross of Jayanti Rohu (Female) $\times$ Rohu (Male) performed better as compared to the embryos of cross of Jayanti Rohu (Male $\times$ Rohum (Female). Jayanti Rohu (Female) $x$ Rohu (Male) showed a faster embryonic development and better survival than Jayanti Rohu (Male) $\times$ Rohu (Female).

\section{Acknowledgement}

The authors thank the Dean, College of fisheries, Head and staff of Department of Fisheries Resource Management and staff of Instructional fishfarm College of Fisheries, Pantnagar for their valuable support and guidance.

\section{References}

Ayyappan, S., Jena, J.K., Gopalakrishnan, A., and Pandey, A.K. 2006. Handbook of fisheries and aquaculture. Directorate of Information and Publications of Agriculture, Indian Council of Agricultural Research, p 755

Bernado, J.H. (1996). Maternal effects in animal ecology, Am. Zool., 36: 83105.

Brown, C.L., Doroshov, S.I., Nunez, J.M., Haley, C., Vaneenennaam, J., Nishioka, R.S., and Bern, H.A. 1988. Maternal triiodothyronine injections cause increases in swimbladder inflation and survival rates in larval striped bass, Morones axatilis. J. Exp. 
Zool. 248:168-17

Caldarone, E.M., Onge-Burns, J.M., and Buckley, L. J. 2003. Relationship of RNA/DNA ratio and temperature to growth in larvae of Atlantic cod Gadus morhua, Mar. Ecol. Prog. Ser., 262: 229-240

Chambers, R.C., Leggett, W.C. 1996. Maternal influences on variation in egg sizes in temperate marine fishes. Am. Zool., 36:180-196

Chambers, R.C., Leggett, W.C., Brown, J.A. 1989 Egg size, female effects, and the correlation between early life history traits of capelin, Mallotu svillosus: an appraisal at the individual level. Fish. Bull. U.S., 87:515- 523

Clutton-Brock, T.H. 1991. The evolution of parental care. Princeton University Press. Princeton, N. J. Pp. 352

DeMarch, B.G.E. 1991. Genetic, maternal and tank determinants of growth in hatchery-reared juvenile Artic charr (Salvelinus alpinus). Can. J. Zool., 69: 655-660

Donelson, J.M., McCormick, M.I., and Munday, P.L. 2008. Parental condition affects early life-history of a coral reef fish. J. Exp. Mar. Biol. Ecol. 360:109116.

Dunham, R.A., and Smitherman, R.O. 1983. Crossbreeding channel catfish for improvement of body weight in earthen ponds. Growth, 47:97-103.

Einum, S., and Fleming, I.A. 1999. Maternal effects of egg size in brown trout (Salmo trutta): norms of reaction to environmental quality. Proc. $R$. Soc. Lond. B, 266: 2095-2100

Green, B.S. (2008). Advances in Marine Biology Volume 54, 2008, Pages 1105

Green, B.S., and McCormick, M.I. 2005. Maternal and paternal effects determine size, growth and performance in larvae of a tropical reef fish. Marine Ecology Progress Series 289:263-272

Heath, D.D., Bernier, N.J., Heath, J.W., and Iwama, G.K. 1993. Genetic, environmental and interaction effects of growth and stress response of Chinook salmon (Oncorhynchus tshawytscha) fry. Can. J. Fish. Aquat. Sci., 50:435-442

Herbinger, C., Doyle, R., Pitman, E., Paquet, D., Mesa, K., Morris, D.,Wright, J., and Cook, D. 1995. DNA fingerprint based analysis of paternal and maternal effects on offspring growth and survival in communally reared rainbow trout. Aquaculture, 137:245256

Hoie, H., Folkvord, A., and Johannessen, A. 1999. Maternal, pater-nal and temperature effects on otolith size of young herring (Clupea harengus L.) larvae. J. Exp. Mar. Biol. Ecol., 234:167-184

Hoie, H., Folkvord, A., and Johannessen, A. 1999. The influence of different parental combinations and incubation temperature on the RNA and DNA content of herring larvae at hatching: a pilot study. J. Fish. Biol., 55:110-118

Kerrigan, B.A. 1997. Variability in larval development of a tropical reef fish (Pomacentridae:

Pomacentrus amboinensis): the parental legacy. Mar. Biol., 127:395-402

Khan, R. A., and Siddiqui, A. Q. 1973. Food Selection by Labeorohita (Ham.) and its Feeding Relationship with other Major Carps. Hydrobiologia, 43: 429442.

Kinghorn, B. P. 1983. A review of quantitative genetics in fish breeding Aquaculture 31(2-4), 283-304.

Majumder, S., Ghosh, P., Saha, S.K., and Saikia, S.K. 2016. Study on food selection of Labeorohita (Hamilton, 1822) by determining electivity index 
in periphyton based and periphyton free monoculture pond. International Journal of Applied Research 2(3): 0407

Marteinsdottir, G., and Steinarsson, A. 1998. Maternal influence on the size and viability of Iceland cod Gadusmorhua eggs and larvae. Journal of Fish Biology, 52: 1241-1258.

McCormick, M.I. 1998. Behaviorally induced maternal stress in a ${ }^{\circledR} \operatorname{shin}^{-}$uences progeny quality by a hormonal mechanism. Ecology 79:1873-1883

McCormick, M.I. 1999. Experimental test of the effect of maternal hormones on larval quality of a coral reef. Oecologia 118:412-422

Sargent, R. 1988. Paternal care and egg survival both increase with clutch size in the fathead minnow, Pimephales promelas. Behav. Ecol.Sociobiol.
23:33-37

Sargent, R. 1997. Parental care. In: Godin JGJ (ed) Behavioural ecology of teleost fishes. Oxford University Press, Oxford, $\mathrm{p} 292-315$

Trippel, E.A., Kraus, G., Köster, F.W. 2005. Maternal and paternal influences on early life history traits and processes of Baltic cod (Gadus morhua). Mar. Ecol. Prog. Ser.303: 259-267.

Wilson, D.T., and Meekan, M.G. 2002. Growth-related advantages for survival to the point of replenishment in the coral reef fish Stegastes partitus (Pomacentridae). Mar. Ecol. Prog. Ser. 231:247-260.

Yamamoto, T.R., Reinhardt, U.G. 2003. Paternal effect on otolithsize at emergence in masu salmon. J. Fish. Biol.62:1226-1231

\section{How to cite this article:}

Vivek Singh Bisht, Anurag Semwal, Sagar Vijay Kuveskar, Vibha Lohani and R.N. Ram. 2018. Maternal and Paternal Characters Affecting the Growth and Survival of Progeny of Jayanti Rohu (Female) $\times$ Rohu (Male) and Jayanti Rohu (Male) $\times$ Rohu (Female) Int.J.Curr.Microbiol.App.Sci. 7(12): 844-855. doi: https://doi.org/10.20546/ijcmas.2018.712.105 